This Journal is available in Telkom University online Journals

Jurnal Manajemen Indonesia

\title{
Measuring Smart Building Readiness Index: A Case Study of Bandung City
}

\author{
Indrawati ${ }^{1}$, Angdini Nurillaily ${ }^{2}$, Husni Amani ${ }^{3}$ and S. K. B. Pillai ${ }^{4}$ \\ 1,2,3 Faculty of Economics and Business, Telkom University, Bandung, Indonesia \\ ${ }^{4}$ Goa Business School, Goa University, Goa, India
}

\begin{abstract}
Government and private players started focusing on developing cities in to smart cities due to increased level of urbanization in most of the countries around the world, including in Indonesia, by focusing on developing new smart buildings and upgrading old ones. Present paper tried to find out the Smart Building Readiness Index (SBRI) of Bandung City for knowing the level of awareness among the general public based on an exploratory research, the result of which enables the authorities to take strategic initiatives for improving the smart buildings and then to smart city status. Required data was collected by conducting in-depth interviews with 30 respondents and the result of the qualitative data revealed that Bandung's SBRI comes to only 64.39, which is not a good indicator but within the limits of fairness and needs lot of improvement in future. The result also can be considered as an indicator that annual energy consumption in Bandung city is still at a high level and needs to focus on improving the quality of buildings in and around Bandung city for the purpose of overall reduction in energy consumption and improvement in quality of environment as well as quality of life. Respondents are also not fully aware of the smart building concept. Much needs to be done for making the public aware of the concept of smart building and its usefulness along with strategically developing smart buildings so that in future Bandung city transforms into a smart city with smart buildings.
\end{abstract}

Keywords - Smart City, Smart Building Readiness Index, Bandung.

\begin{abstract}
Abstrak
Pemerintah dan swasta mulai fokus mengembangkan kota-kota berkembang karena meningkatnya tingkat urbanisasi di sebagian besar negara di dunia, termasuk di Indonesia, dengan fokus pada pembangunan smart building dan peningkatan gedung-gedung tua. Makalah ini mencoba untuk mengetahui Indeks Kesiapan Bangunan Cerdas (SBRI) Kota Bandung untuk mengetahui tingkat kesadaran masyarakat umum berdasarkan penelitian eksplorasi, yang hasilnya memungkinkan pihak berwenang untuk mengambil inisiatif strategis untuk perbaikan smart building dan lalu ke status smart city. Data yang diperlukan dikumpulkan dengan melakukan wawancara mendalam dengan 30 responden dan hasil data kualitatif menunjukkan bahwa SBRI Bandung hanya 64,39, yang bukan merupakan indikator yang baik tetapi masih dalam batas kewajaran dan perlu banyak perbaikan di masa mendatang. Hasil tersebut juga dapat dianggap sebagai indikator bahwa konsumsi energi tahunan di kota Bandung masih berada pada tingkat yang tinggi dan perlu difokuskan pada peningkatan kualitas bangunan di dalam dan sekitar kota Bandung untuk tujuan pengurangan konsumsi energi secara keseluruhan dan peningkatan kualitas. lingkungan serta kualitas hidup. Responden juga belum sepenuhnya mengetahui konsep smart building. Banyak yang harus dilakukan untuk menyadarkan masyarakat akan konsep smart building dan kegunaannya seiring dengan pembangunan smart building yang strategis sehingga di masa depan kota Bandung bertransformasi menjadi smart city.
\end{abstract}

Keywords-Smart City, Smart Building Readiness Index, Bandung.

Article info

Received (11/12/2019)

Revised (29/04/2020)

Accepted (30/06/2020)

Corresponding_author: indrawati@telkomuniversity.ac.id

DOI: $10.25124 /$ jmi.v20i2.3201

Copyright@2020. Published by School of Economics and Business - Telkom University 


\section{INTRODUCTION}

According to the report on World Urbanization Prospects (UN, 2018), 66\% of the Asia's population is going to be living in urban cities by 2050 , which shows the need for strategically developing the urban areas around the world into smart cities with smart buildings which minimizes energy consumption as it contributes to around $40 \%$ of the total annual energy consumption. The concept of smart buildings is aimed at achieving not only savings in energy consumption but also increased convenience and benefits to various stakeholders, namely, building users, owners, tenants and smart service providers as smartness adds, creates, and generates value to the buildings.

The benefits of having a smart building include increased safety and security, increased comfort and convenience, reduction in $\mathrm{CO} 2$ emissions, and reduction in operational costs (heating, cooling and lighting). Study result published in Harvard Business Review (HBR, 2016) shows that smart buildings help in saving up to $30 \%$ of water usage, $50 \%$ of natural gas usage and $40 \%$ energy usage, hence smart buildings are considered as critical and a pre-condition for transforming a city in to a smart city (HBR, 2016; Aliya, 2017). Countries around the world started transforming their urban cities into smart cities, including Indonesia, and Bandung city in West Java was the only finalist from Southeast Asia for the World Smart City Award in 2015 along with Buenos Aires from Argentina, Curitiba from Brazil, Dubai from UAE, Moscow from Russia and Peterborough from UK (Maulani, 2015). This was the main reason for carrying out the present study to assess the SBRI in Bandung so one can see how far away is Bandung city in becoming a smart city and also the level of awareness among the general population so as to impart required information to the general public about the significance of having smart buildings for the purpose of overall reduction in the usage of precious natural resources which leads to improvement in overall quality of environment and also the quality of life of the residents of Bandung city.

Bandung city, capital of West Java Province, is going to celebrate its $209^{\text {th }}$ anniversary on $25^{\text {th }}$ September 2019. During the last 200 years time, one can see that Bandung city has been expanded in a big way, and Figure 1 demonstrates the expansion during 1811-2007 due to the rapid developments of the built-up area, which clearly provides the population density also, which leades to the increased concern for making Bandung a sustainable city. Year after year, the authorities and various stakeholders are trying to ensure that the city is retaining its position of the most sought after city.

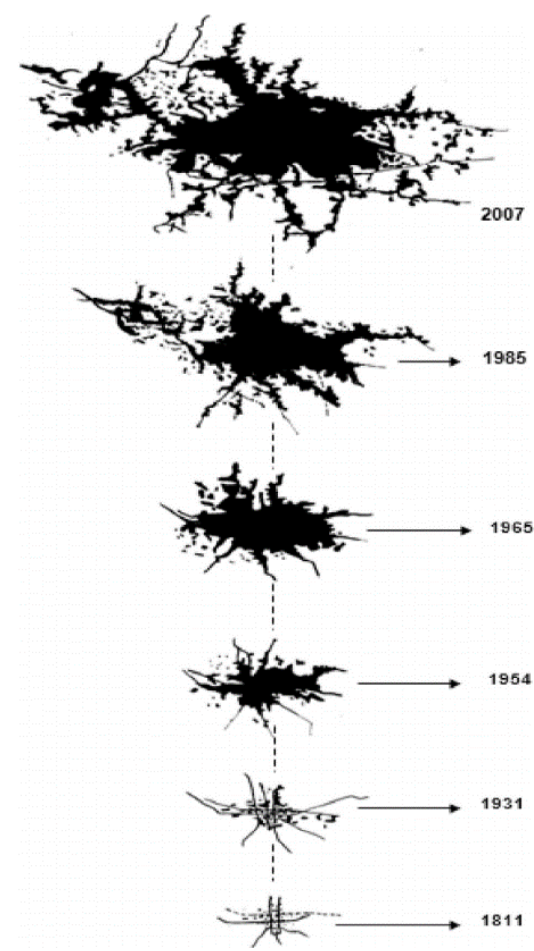

Figure 1. The Expansion of Bandung City's built-up area 
Over the years, Bandung managed to reach the top position among other cities of Indonesia in terms of highest economic growth which attracts both large domestic and foreign investments to develop required infrastructure for promoting healthy business environment for entertainment industry, financial services, manufacturing sector (textile and apparels, food processing, and pharmaceutical), and also in tourism and hospitality services. This lead to inceased flow of people from other regions for starting business and also for settling down. The popolation of Bandung according to BPS West Java is above 2.5 million, almost the same size of Medan with 2.496 million (first being Surabaya with 2.8 million) and the total area comes to around $167.2965 \mathrm{~km}^{2}$, resulting in becoming the $40^{\text {th }}$ most populated city in the world with a populaiton density of 18,416 people per $\mathrm{km}^{2}$ (Voskuil, 2007).

To have the smart city status to Bandung city, previous mayor of Bandung, Ridwan Kamil issued a regulation on green building which insists on having at least $50 \%$ green cover of trees and installing energy saving instrument, which are compulsory for those buildings constructed after 2017 (Aliya, 2017). So far only three buildings are considered as smart buildings in Bandung, namely, Bandung Creative Hub as a public space, Library and Archives office as Government office and Hotel Crown as residential building, hence the relevance of carrying out the present study.

The present urbanization rate in Indonesia is around $4.1 \%$ per year which is the fastest among the Asian countries (World Bank, 2016), indicating the need for developing urban cities into smart cities by constructing smart buildings in Indonesia. The present study is focusing on Bandung city to explore the possibility of improving its status of a smart city to a higher level in future by focusing on various variables and indicators used for measuring the smart building identified in earlier (Indrawati et al, 2017; Indrawati et al, 2019) for developing Bandung city's SBRI. The three research questions (RQ) which the present paper tries to answer are, RQ1: How to measure Bandung city's SBRI ?, RQ2: What is the level of readiness of Bandung city to become smart city?, and RQ3: What residents of Bandung think about smart buildings?.

\section{Research Methodology}

The present study is divided in to two sections, initially an attempt is made to find out Bandung city's SBRI and then understanding the level of awareness among the general public regarding the concept of smart building. The calculation of SBRI is carried out in six stages, firstly reviewing and confirming the variables and indicators of smart building, secondly identifying best practices data for smart building implementation indicators from around the world, thirdly finding the data for smart building implementation indicator for Bandung, fourthly conducting in-depth interview and collecting qualitative and quantitative data, fifthly calculating individual scores of each variables and indicators to ensure the validity for including in the final model, and finally calculating the SBRI for Bandung city. The stages of the first section can be shown in Figure 1.

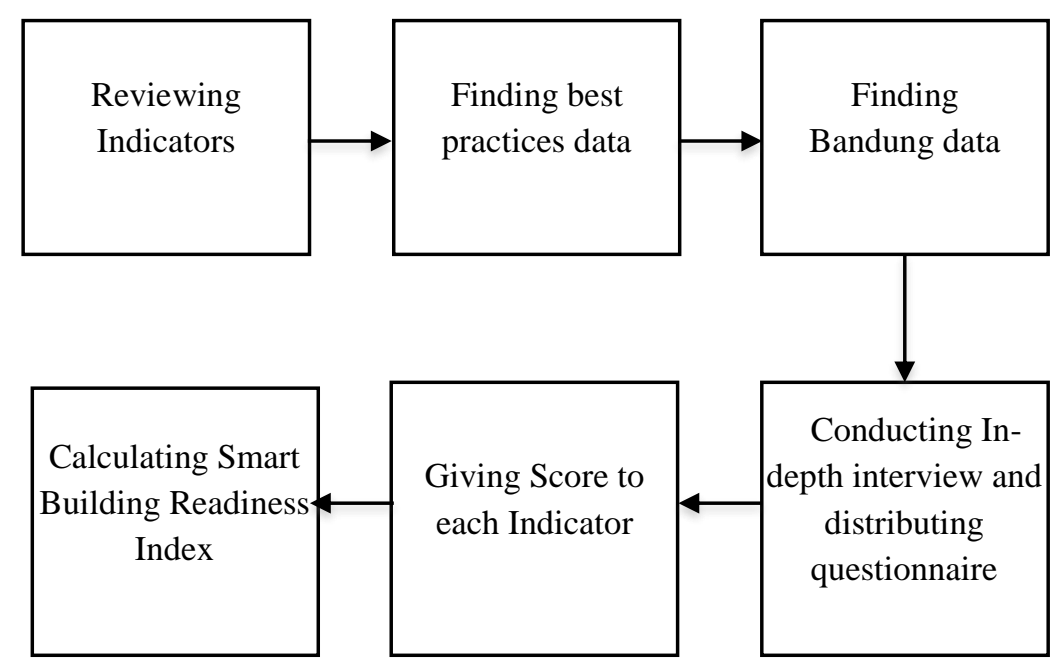

Figure 2. Research Stages 
Level of awareness among the general public when it comes to what constitutes smart building is analysed using data from one of the social media, namely, Twitter, mainly used by the Bandung city officials for engaging general public for supporting government programs. Different set of key words are used for assessing the level of awareness, to name a few, \#bdg, \#bandung, \#bangunpintar, \#smartbuilding, @humasBdg, @BDG_CommandCtr, @pemkoBandung, @pembdg, @distaruBDG and @ppidkotabandung. Around 1,472 tweets are taken for the analysis, though the size of the sample is not considered sufficient for big data analytic, which needs to be explored further with an even larger sample in the subsequent studies. The most and least frequently used words are finally represented in the form of word cloud illustration.

Both qualitative and quantitative data was used in obtaining SBRI. Qualitative data was used for assessing and confirming the smart building status based on various variables and indicators. In-depth survey was carried out with people from quadruple helix parties, namely, government, business people, experts or researchers and users or society for identifying the variables and indicators used for measuring smart building and confirming the validity also of the identified variables and indicators. Quantitative date is used for calculating the scores for developing SBRI, which was based on the best practice data from other countries which have already implemented smart building index (Creswell, 2009; Indrawati, 2015). The data was collected using nonprobability sampling method, namely, purposive sampling (Indrawati, 2015; Zikmund et al, 2010) from four categories of respondents, the details of which are given in Table 1.

Table 1. List of Respondents

\begin{tabular}{llc}
\hline Category & Respondents & Number \\
\hline $\begin{array}{l}\text { Experts / } \\
\text { Researchers }\end{array}$ & Expert from smart city consultant and Universities & $\mathbf{4}$ \\
\hline Government & $\begin{array}{l}\text { Department of Communication and Informatics Bandung } \\
\text { Bandung City Planning Service } \\
\text { Program design and Building Quality Bandung } \\
\end{array}$ & $\mathbf{7}$ \\
\hline Bandung City Design and Building Program & $\begin{array}{l}\text { Bandung private companies that engaged in the field of building procurement } \\
\text { for smart building }\end{array}$ & $\mathbf{1 0}$ \\
\hline User & People who know about technology of smart building & $\mathbf{1 0}$ \\
\hline Total & & $\mathbf{3 1}$ \\
\hline
\end{tabular}

\section{A. Validation of Smart Buildings Indicators and Variables}

Seven variables to measure the smart building are identified in an earlier work by Indrawati et al. (2017) and Indrawati (2019), namely, building automation system, building control system, energy management system, safety and security management system, enterprise management system, IT network connectivity, and green building construction. These seven variables have 22 indicators, which are used in the present study after validating the same before calculating SBRI. The details of all the 22 indicators / constructs of the seven variables with their validity test result is shown in Table 2.

The scores so collected by the respondents are then tested for their validity using Pearson product moment correlation and the resulting value of at least 0.361 is considered valid with an error rate of 0.05 . Those variables having less than 0.361 is considered as invalid which needs to be exclude from the calculation of SBRI. Cronbach alpha also applied to all the variables to see the overall validity.

\section{B. Level of Bandung city's SBRI and Public Perception of Smart Building.}

The validation of the variables and the relevant indicators are carried based on the in-depth survey data collected from the respondents with an aim of exploring the possibility of adding or accommodating a new indicator(s) and variable(s). Respondents are asked to score (ranging from 1 to 100) each of the 22 indicators of the seven variables, which allows the indicators to be grouped in to five categories, namely, score 1-60 indicating worst performance scenario which needs lot of improvement, score between 61-70 indicating bad performance scenario which needs lot of improvement, score between 71-80 indicating good and enough performance scenario still needs lot of improvement, score between 81-90 indicating good and satisfying performance scenario which needs little improvement and score between 91-100 indicating very good performance scenario where no improvement is required. The calculation of SBRI is carried out in two stages, namely, firstly calculation of 'Indicator Index' and then 'Smart Building Index'. 


$$
\text { Indicator Index }=\frac{\Sigma x}{\Sigma y}
$$

Where: $\Sigma \mathrm{x}=$ Total score of an indicator given by respondents.

$\Sigma y=$ Total respondent who give score for an indicator.

$$
\text { Smart Building Index }=\frac{\Sigma I i}{\Sigma T i}
$$

Where: $\Sigma \mathrm{Ii}=$ Total average score of all indicators given by respondents . $\Sigma \mathrm{Ti}=$ Total indicators.

\section{RESULT AND DISCUSSION}

As mentioned, the validation of the variables and the relevant indicators, which are carried out based on the in-depth survey data collected from the respondents with an aim of exploring the possibility of adding or accommodating a new indicator(s) and variable(s) and also and also subtracting or removing an existing indicator(s) and variable(s). The initial result of Pearson product moment correlation reveals that except for two, rest of the 20 indicators/variables are having the value of above 0.361 . The result of the validity test shown in Table 2 indicates that except two constructs, namely, "implementation of security framework and cyber security" (indicator number 11 of variable 4) and "all devices connected with multi-service communication" (indicator number 17 of variable 6), remaining all the constructs are valid. These two indicators are removed while calculating the SBRI. Subsequently, Cronbach Alpha was also calculated to ensure the reliability and found to be above 0.70 for all seven variables and 20 indicators.

Based on the secondary data from the best practices in smart cities from the 2018 Global Cities Index Ranking (Peña et al., 2018), Bandung city data was collected as explained in the previous section based on the 20 indicators (2 indicators were invalid and removed from the SBRI calculation) of the seven variables which determine the status of building as smart building or not. As mentioned, respondents are asked to score (ranging from 1 to 100) each of the 22 indicators of the seven variables, which are then classified in to five categories in terms of their performance as, score 1-60 as worst, 61-70 as bad, 71-80 as good and enough, 81-90 as good and satisfying, and finally 91-100 as very good. The result of the 'Indicator Index' and 'Smart Building Index', after removing the two indicators, is given in Table 3.

\begin{tabular}{|c|c|c|c|c|c|}
\hline \# & Variables & & Indicators & $\mathbf{r}$ & Validity \\
\hline 1 & $\begin{array}{l}\text { Building automation } \\
\text { system }\end{array}$ & 1 & Sensors implementation & 0.767 & Valid \\
\hline \multirow[t]{3}{*}{2} & Building control system & 2 & Remote monitoring implementation & 0.475 & Valid \\
\hline & & 3 & Real-time monitoring implementation & 0.822 & Valid \\
\hline & & 4 & $\begin{array}{l}\text { Implementation of any software that can talk to legacy } \\
\text { equipment from many different manufacture }\end{array}$ & 0.835 & Valid \\
\hline \multirow[t]{3}{*}{3} & Energy management & 5 & Implementation of power consumption and monitoring & 0.853 & Valid \\
\hline & system & 6 & control & 0.605 & Valid \\
\hline & & 7 & $\begin{array}{l}\text { Implementation of energy efficient electrical appliances } \\
\text { Implementation of backup energy }\end{array}$ & 0.787 & Valid \\
\hline \multirow[t]{6}{*}{4} & Safety and security & 8 & Implementation of threat detection and response & 0.644 & Valid \\
\hline & management system & 9 & Implementation of controlling access facility & 0.456 & Valid \\
\hline & & 10 & Implementation of securing lives and assets & 0.614 & Valid \\
\hline & & 11 & Implementation of security framework and cyber & 0.086 & Not \\
\hline & & 12 & security & 0.826 & Valid \\
\hline & & & Publish safety and privacy policy & & Valid \\
\hline \multirow[t]{3}{*}{5} & Enterprise management & 13 & Data management framework & 0.610 & Valid \\
\hline & system & 14 & System information management & 0.868 & Valid \\
\hline & & 15 & Data analytic & 0.522 & Valid \\
\hline \multirow[t]{4}{*}{6} & IT network connectivity & 16 & Wired / wireless communication & 0.727 & Valid \\
\hline & & 17 & All devices connected with multi service communication & 0.056 & Not \\
\hline & & 18 & Availability and reliability of network & 0.596 & Valid \\
\hline & & & & & Valid \\
\hline 7 & Green building & 19 & Green building architecture & 0.719 & Valid \\
\hline
\end{tabular}

Table 2. Validity Test Result of Smart Building Variables and Indicators 


\begin{tabular}{lllll}
\hline construction & 20 & Low environment impact & 0.747 & Valid \\
& 21 & Resource efficiency & 0.487 & Valid \\
& 22 & Healthy environment & 0.537 & Valid \\
\hline
\end{tabular}

The scenario of the smart building readiness given in the last column clearly indicates that Bandung is still considered poor, out of the 20 indicators, six are coming under 'worst scenario', eight are coming under 'bad scenario' and only six are coming under 'good scenario'. Only 'Green building construction (variable 7)' is having all indicators having 'good scenario', whereas the indicators of 'Enterprise management system (variable 5)' and 'Building control system (variable 2)' are coming under 'worst scenario'. The main reason for such a poor scenario in Bandung city is the fact that the government was mainly focusing on 'green building regulation' (Aliya, 2017) as a precondition for smart building which resulted in neglecting other variables which are critical for making smart buildings.

Table 3. Indicator Scores and Smart Building Readiness Index

\begin{tabular}{|c|c|c|c|c|c|}
\hline \# & Variables & & Indicators / Constructs & Score & Scenario \\
\hline 1 & $\begin{array}{l}\text { Building automation } \\
\text { system }\end{array}$ & 1 & Sensors implementation & 65.07 & Bad \\
\hline \multirow[t]{3}{*}{2} & Building control system & 2 & Remote monitoring implementation & 60.73 & $\mathrm{Bad}$ \\
\hline & & 3 & Real-time monitoring implementation & 49.00 & Worst \\
\hline & & 4 & $\begin{array}{l}\text { Implementation of any software that can talk to legacy } \\
\text { equipment from many different manufacture }\end{array}$ & 56.20 & Worst \\
\hline \multirow[t]{3}{*}{3} & Energy management & 5 & Implementation of power consumption and monitoring & 62.73 & Bad \\
\hline & system & 6 & control & 68.87 & Bad \\
\hline & & 7 & $\begin{array}{l}\text { Implementation of energy efficient electrical appliances } \\
\text { Implementation of backup energy }\end{array}$ & 62.27 & Bad \\
\hline \multirow[t]{6}{*}{4} & Safety and security & 8 & Implementation of threat detection and response & 65.83 & $\mathrm{Bad}$ \\
\hline & management system & 9 & Implementation of controlling access facility & 72.97 & Good \\
\hline & & 10 & Implementation of securing lives and assets & 67.53 & Bad \\
\hline & & 11 & Implementation of security framework and cyber & removed & --- \\
\hline & & 12 & security & 57.00 & Worst \\
\hline & & & Publish safety and privacy policy & & \\
\hline \multirow[t]{3}{*}{5} & Enterprise management & 13 & Data management framework & 58.90 & Worst \\
\hline & system & 14 & System information management & 54.77 & Worst \\
\hline & & 15 & Data analytic & 40.00 & Worst \\
\hline \multirow[t]{3}{*}{6} & IT network connectivity & 16 & Wired / wireless communication & 73.77 & Good \\
\hline & & 17 & All devices connected with multi service communication & removed & --- \\
\hline & & 18 & Availability and reliability of network & 68.97 & $\mathrm{Bad}$ \\
\hline \multirow[t]{5}{*}{7} & Green building & 19 & Green building architecture & 74.90 & Good \\
\hline & construction & 20 & Low environment impact & 75.87 & Good \\
\hline & & 21 & Resource efficiency & 78.10 & Good \\
\hline & & 22 & Healthy environment & 74.40 & Good \\
\hline & & & Smart Building Readiness Index & 64.39 & Bad \\
\hline
\end{tabular}

The result also revealed very low awareness among general public with respect to what constitutes smart building and smart city hence builders are not bothered about providing all the facilities while constructing buildings resulting in only three smart buildings presently existing in Bandung city which leads to the situation where smart building technology providers lack of interest in providing necessary infrastructure and services which otherwise would have led to increase in smart buildings in Bandung city. Public in general still favours manual system rather than exploring and adopting automated systems when it comes to the usage of buildings in Bandung.

Though the awareness among the public about the smart buildings and smart city is very low, Bandung city official's uses social media to engage public to support various government programs. And the data gathered from the Twitter of 1,472 tweets clearly shows the level of awareness among the general public in Bandung city. The result of the word cloud illustration from the data gathered from Twitter is given in Figure 2, indicating that the perception of smart building among the general public in Bandung city is very low and insignificant. The big words appear in the world cloud are "humasbdg, pembdg, giat, kelurahan, antonsugiana" instead of smart building". This needs to be tackled by providing proper education about the benefits of smart buildings and smart cities which might improve the status of Bandung with respect to smart building and smart cities in future. 


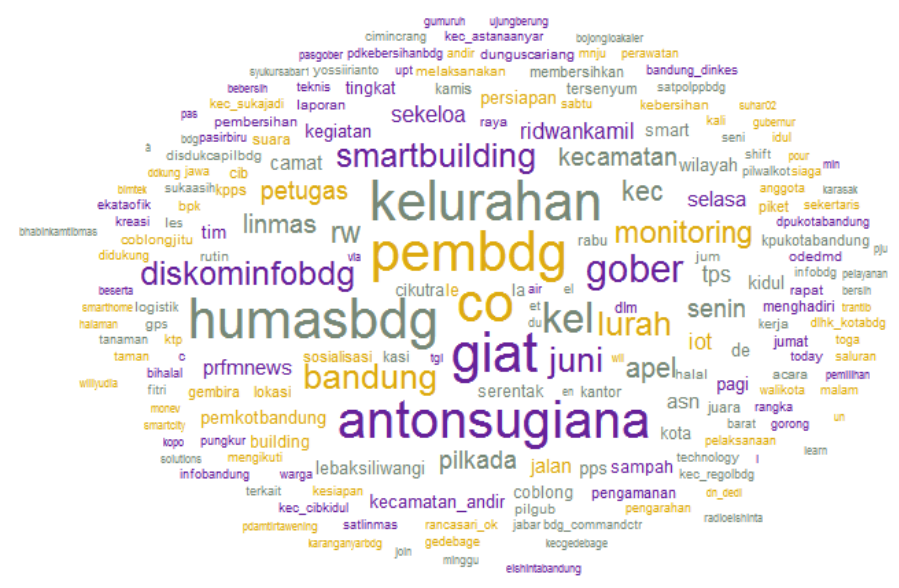

Figure 2. Word Cloud Illustration (Source: word cloud result)

\section{CONCLUSION}

Present study identified seven variables and 20 indicators for measuring Bandung city's SBRI, which resulted in only 64.39 leading to the conclusion that Bandung city is very poor when it comes to smart building implementation, which was the reason why Bandung remained as one of the top finalists of World Smart City Award in 2015 and no change taken place during 2015 till now. Among the indicators, the best indicator is 'resource efficiency' with a score of 78.10 and the worst indicator is 'data analytic' with a score of 40.00. Only the variable 'Green building construction' have all its indicators falling under 'good scenario', whereas the indicators of 'Enterprise management system' and 'Building control system' are falling under 'worst scenario'. Bandung city mainly focused on 'green building regulations' as the primary aspect of smart building, but now focus must be on the remaining six variables, namely, building automation, building control, energy management, safety and security management, enterprise management and also IT network connectivity. Bandung city officials must also focus on improving the public awareness of the benefits of using automated systems by providing required facilities for switching over from manual systems on a gradual basis. A well planned socialization program must be developed by including various stakeholders, especially the educational institutions which may take up the initiative of imparting the education on the benefits of having smart buildings and smart cities, first by developing their institutions as a smart institutions with smart buildings so the student community (future of Indonesia) learn about the benefits in terms of preserving precious resources and improving overall environmental quality and ultimately the quality of life of all people. Well educated and well informed general public helps Bandung city in improving its status to a smart city in the coming years. Further longitudinal study may be carried out once the authorities starts implementing the awareness programs and implementation of smart building concept in the coming years.

\section{REFERENCES}

Aliya, A. (2017). Terapkan Aturan Green Building, Bandung Bisa Hemat Rp 200 Miliar. Detik Finance. [online] https://finance.detik.com/berita-ekonomi-bisnis/3330652/terapkan-aturan-green-buildingbandung-bisa-hemat-rp-200-miliar (Accessed 15 July 2018)

Creswell, J.W. (2009). Research Design, Quantitative, Qualitative and Mixed Method, Sage, London. HBR (2016). SMART CITIES START WITH SMART BUILDINGS. HARDVARD BUSINESS REVIEW. [online] https://hbr.org/sponsored/2016/01/smart-cities-start-with-smart-buildings (Accessed 14 Juni 2018)

Indrawati. (2015). Metode Penelitian Manajemen dan Bisnis, PT. Refika Aditama,Bandung

Indrawati, Yuliastri, R., \& Amani, H. (2017). Indicators to Measure a Smart Building: An Indonesian Perspective. International Journal of Computer Theory and Engineering, 9(6), 406-411. DOI: 10.7763/IJCTE.2017.V9.1176. [online] Http://www.Ijcte.Org/List-92-1.Html (Accessed 1 August 2018). 
Indrawati. (2019). Inilah Cara Mengukur Tingkat Kecerdasan Suatu Kota Inteligensia Media.Bandung.

Maulani. A. M. A (2015). Bandung is a finalist in the World Smart City Awards [online] https://e27.co/bandung-finalist-world-smart-city-awards-20151118/ (Accessed 4 August 2019).

Peña, A. M., Hales, M., Peterson, E. R., \& Dessibourg, N. (2018). 2018 Global Cities Report Learning from the East: Insights from China's Urban Success. [online] https:/www.atkearney.com/2018-global-citiesreport (Accessed 18 December 2018).

United Nation. (2018). World Urbanization Prospects. [online] https://population.un.org/wup/Country-Profiles/ (Accessed 10 October 2018)

Voskuil, R. P. G. A (2007). Bandung, Citra Sebuah Kota (Bandung image of a city), Bandung, Department of City and Regional Planning: Institut Teknologi Bandung and PT. Jaggadhita.

World Bank. (2016). Kisah Urbanisasi Indonesia. [online] http://www.worldbank.org/in/news/feature/2016/06/14/indonesia-urban-story (Accessed 10 June 2018)

Zikmund, W.G., Babin, B.J., Carr, J.C., \& Griffin, M. (2010). Business Research Methods, Eighth Edition. Cengage Learning Singapore. 